\title{
THE EFFECT OF SOLIDS ON THE BEHAVIOUR OF THE DOWNCOMER OF A JAMESON CELL
}

\author{
Ramiro Escudero, Eloy Tapia, Ricardo Morales \\ Instituto de Investigaciones en Metalurgia y Materiales, Universidad Michoacana de San Nicolás de Hidalgo, \\ Morelia 58000, Mexico. Tel/Fax: (+52) 4433223500 ex. 4018 \\ *Corresponding autor: ramiro1963@gmail.com
}

\begin{abstract}
The effect of solids on the behaviour of the downcomer of a Jameson cell was studied in terms of the hydrophobic/hydrophilic character of the solids. Hydrophobic (carbon), and hydrophilic (silica sand) solids were used, separately. The experiments were carried out under controlled conditions of gas flow rate, pulp flow rate, and pulp consistency. The observed operating variables were the extension of the downcomer operating regions (pulp jet, mixing, and collection) and gas hold-up. It was observed that gas bubbles are smaller and more uniform in size when the pulp is comprised of silica (hydrophilic particles), as compared with pulps consisted of carbon (hydrophobic particles).

When measuring a profile of gas holdup in the separation cell, experimental results show that a more homogeneous radial holdup distribution is achieved in the case of a slurry with silica sand rather than the pulp made of carbon.
\end{abstract}

Key words: Jameson cell, downcomer, separation cell, superficial phase velocity, gas hold-up, hydrophobic solids, hydrophilic solids.

\section{INTRODUCTION}

Inverted flotation columns, or Jameson cells, were developed initially to separate, by froth flotation, fine particles, which normally are difficult to float in conventional flotation systems (mechanical cells and flotation columns) [1]. The effectiveness of flotation process in the Jameson cell has been shown even in non mineral separation processes, as for instances recovering organics in solvent extraction applications. [2, 3, 4]

The Jameson cell comprises two bodies: the downcomer and the separation cell. The down-comer constitutes the inverted bubbling column, and in this part of the cell, both the slurry and the gas bubbles are in close contact forming hydrophobic solids-bubble aggregates. The slurry and the aggregates are discharged down into the separation cell. Because of its diameter, the separation cell observes a smaller superficial phase velocities when compared to the downcomer. This allows the aggregates to float and be collected at the surface of the cell as concentrate.

Depending on the physicochemical characteristics of the slurry-gas dispersion and operating parameters such as the superficial gas and slurry velocities in the downcomer, the resulting extension of the operating zones (free slurry jet, mixing, and collection), bubble size, and gas hold-up in the downcomer can be controlled; therefore, the product from the downcomer, which depends from the operating conditions, affects the behaviour of materials in the separation cell, determining the characteristics of axial and radial circulation and mixing, as reported by Koh and Schwarz [5], mentioning that the local value of the turbulent dissipation rate has a direct influence on the local particlebubble detachment rate.
Regarding the effect of operating conditions (nozzle diameter, downcomer diameter, jet velocity, and jet length), on the Jameson cell performance, Tasdemir and co-workers $[6,7]$, concluded that downcomer diameter observes a very little effect on gas entrainment rate while increasing values of other factors had an increasing effect on it.

The effect of solids content (hydrophobic and hydrophilic solids) fed to a Jameson cell is analysed in terms of the downcomer behaviour.

\section{EXPERIMENTAL}

The experiments were carried out in a laboratory Jameson cell (downcomer: $5 \mathrm{~cm}$ in diameter, $180 \mathrm{~cm}$ in length; separation cell: $50 \mathrm{~cm}$ in diameter, $100 \mathrm{~cm}$ in length), made of transparent acrylic plexiglass.

The slurry and the air were fed separately into the downcomer through inlets located at its top. The flowrates of the feed (1.7 to $6.1 \mathrm{~L} / \mathrm{min}$ ), and tailings were controlled by means a peristaltic pumps (Masterflex: $0-20 \mathrm{~L} / \mathrm{min}$ ). The fed gas $(0.17$ to $2.11 \mathrm{~L} / \mathrm{min})$ was fixed and controlled using an automatic air mass flow meter. Both the superficial gas and liquid flowrate ( $\mathrm{Jg}$, and $\mathrm{Jl}$, respectively) are referred to the downcomer cross-sectional area.

Tap water was mixed with carbon or silica particles $\left(\mathrm{D}_{80}=-\right.$ $30 \mu \mathrm{m})$, separately, to form low density slurries ( $1 \%$ and $2 \%$ solids (w/w)). The slurries were fed into the Jameson cell after conditioning in a tank with a certain amount of surfactant (MIBC).

Gas hold-up was estimated in the downcomer through conductivity measurements (Tacussel électronique; CDRV 
62) of both, the slurry only and the slurry-gas dispersion, by applying the Maxwell's conductivity model: [4]

$$
\varepsilon=\left[1-\left(\kappa_{\mathrm{d}} / \kappa_{\mathrm{l}}\right)\right] /\left[1+0.5\left(\kappa_{\mathrm{d}} / \kappa_{\mathrm{l}}\right)\right]
$$

being $\kappa_{\mathrm{d}}$ the conductivity of the dispersion (in this work is the conductivity of the gas-slurry) and $\kappa_{1}$ the continuum conductivity (in this work is the slurry only conductivity); and $\epsilon_{\mathrm{g}}$ is the volumetric fraction of the non conducting dispersed phase (or the dispersed gas bubbles) named gas hold-up. Therefore, once the slurry only conductivity and the gas-slurry conductivity are known, the gas hold-up can be estimated.

Maxwell's conductivity model has proven to be an accurate and reliable method to estimate the volumetric fraction of non conducting phase dispersed in a conducting continuum. $[8,9]$

The conductivity of the slurry (continuous phase), with no air, was continuously measured through a flow cell installed in the top point of the downcomer, in this way the property $\kappa_{1}$ in Maxwell's model (eq. (1)) is known; on the other hand, the electrical conductivity of the slurry-gas dispersion $\left(\kappa_{d}\right)$ is constantly measured by using a conductivity flow cell located at the outlet of the downcomer [10]. With the proper knowledge of both $\kappa_{\mathrm{l}}$, and $\kappa_{\mathrm{d}}$, the gas holdup can be estimated (eq. (1)).

Radial and axial profiles of gas hold-up and superficial gas velocity, in the separation cell, are estimated by using a laboratory home-made probe. [11] In this case, the slurry only conductivity and the conductivity of the gas-slurry dispersion are measured by using the "gas separation method." [12]. This method consists in measuring the gasslurry dispersion conductivity, $\kappa_{d}$, with an open conductivity flow cell, while the slurry only conductivity, $\kappa_{l}$, is measured in a siphon conductivity flow cell, where the gas bubbles are excluded. Therefore equation (1) can be applied to estimate the gas holdup in the point of measurement. The probe is presented in Figure 1, whereas the experimental apparatus is shown in Figure 2.

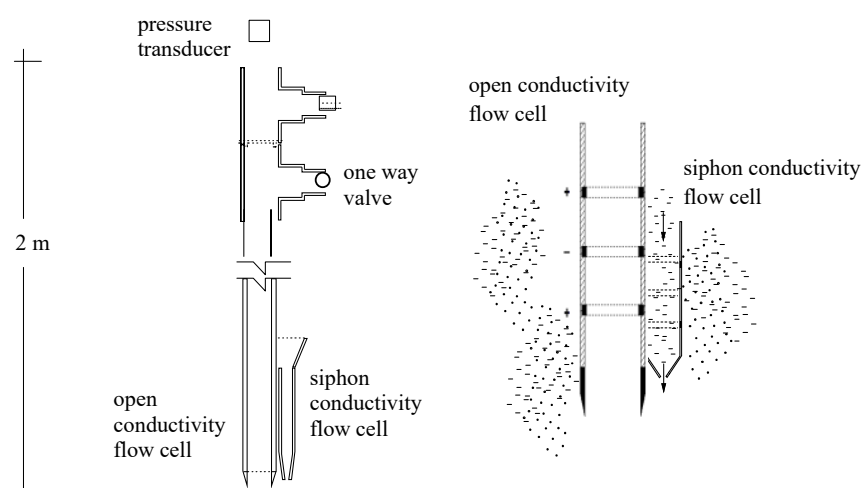

Figure 1. Gas holdup probe to measure the superficial gas velocity [8], the conductivity of the gas-slurry dispersion

(open conductivity flow cell), and the slurry only conductivity (siphon conductivity flow cell [9].

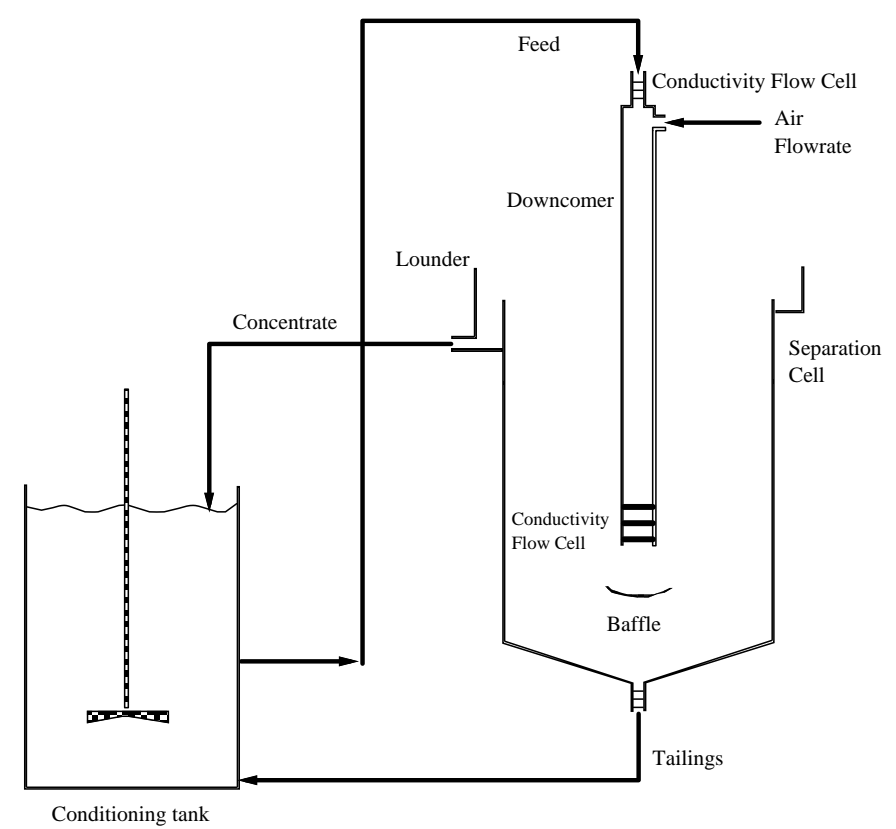

Figure 2. Schematic representation of the experimental setup.

\section{RESULTS AND DISCUSSION}

It has been experimentally observed that the hydrophobic degree of a dispersed phase in a gas-liquid dispersion has an effect on bubbles coalescence conduct, and therefore on the gas hold-up behaviour of the dispersion; this demeanour, in turn, will affect the circulation-mixing patterns in such dispersions. [13]

The addition of hydrophobic or hydrophilic solids in an aqueous phase in amounts to produce low consistency slurries is visualised in Figures 3 and 4 in terms of the gas hold-up as a function of the superficial gas velocity in the downcomer.

Figure 3 shows the stability range of the operating conditions ( $\mathrm{Jg}$ and $\mathrm{Jl}$ ), on the existence of collection zone in the down-comer as a proper performance of the flotation process. There is observed that the collecting zone in the downcomer increases with the superficial slurry velocity. It is important to visualise the operation of the downcomer where apparently the gas and slurry flows in co-current; however, there is a counter-current flow between these phases, the slurry moving downwards while the gas bubbles move upwards in the slurry. Under this scene, larger bubbles will be retained for longer periods of time as compared with small bubbles which are easily transported downwards by the stream. 


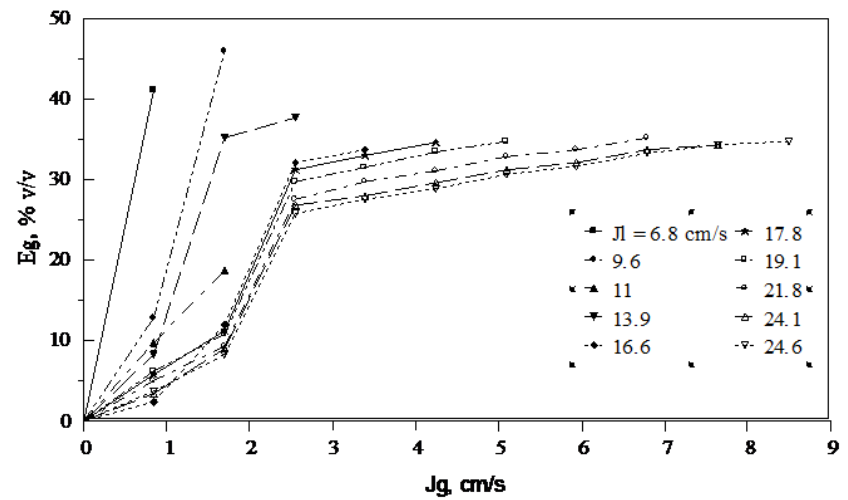

Figure 3. Effect of the superficial gas (Jg), and slurry velocities (Jl), on the gas hold-up in the downcomer. Slurry with $1 \%(\mathrm{w} / \mathrm{w})$ of carbon particles, and without frother.

The large retention time of the gas bubbles in the downcomer will create large gas holdup values. It has been pointed out that hydrophobic solids may induce bubbles coalescence resulting in the formation of larger bubbles. [14] In carbon slurries - gas systems, the carbon particles present a hydrophobic behaviour and, therefore, formation of large bubbles is likely to occur because of bubbles coalescence induced by the hydrophobic nature of the carbon particles, as it was visually observed in these experimental systems.

The effect of hydrophilic solids on the downcomer performance is presented in Figure 4 where silica slurriesgas systems are illustrated. Silica is a well known hydrophilic material, this characteristic is due to the formation of silanol groups on its surface when it is immersed in aqueous media. It can be observed that operating superficial slurry velocity (in the downcomer) is restricted to a narrower range. This behaviour is caused by the production of small bubbles whose coalescence is prevented by the presence of the hydrophilic particles of silica.

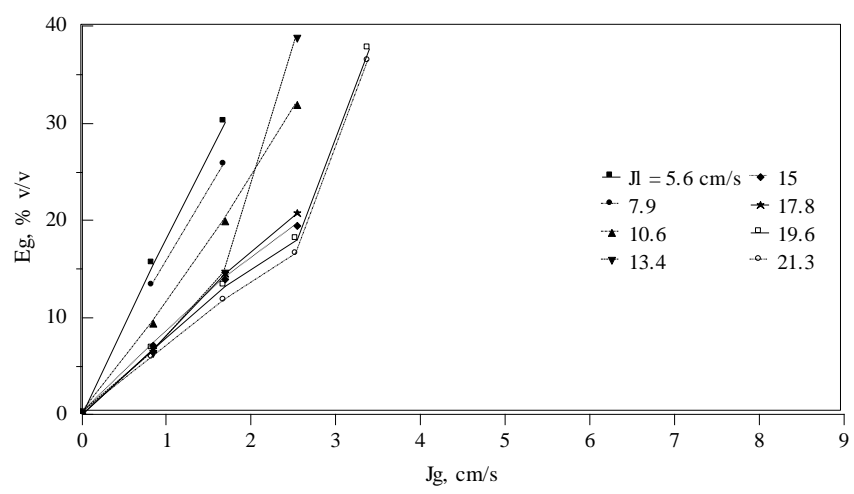

Figure 4. Gas Holdup behaviour in the downcomer as a function of both the superficial gas and liquid velocities. Silica-water slurry without frother (surface tension of the liquid $=72 \mathrm{dyn} / \mathrm{cm}), 1 \%(\mathrm{w} / \mathrm{w})$ solids .
In light of the above, small bubbles present a small resistance to the slurry flow to maintain the packed bed of bubbles into the slurry stream in the downcomer collection zone, being pushed downwards by the gas that is fed into the downcomer, decreasing the extension of the collection zone, and then being replaced by the jet zone. This effect is compensated by increasing the superficial slurry velocity in the downcomer in order to sustain a proper collection zone operation.

The effect of increasing the slurry consistency by adding carbon or silica up to $2 \%$ is presented in Figures 5 and 6. These flotation systems are performed with surfactant additions.

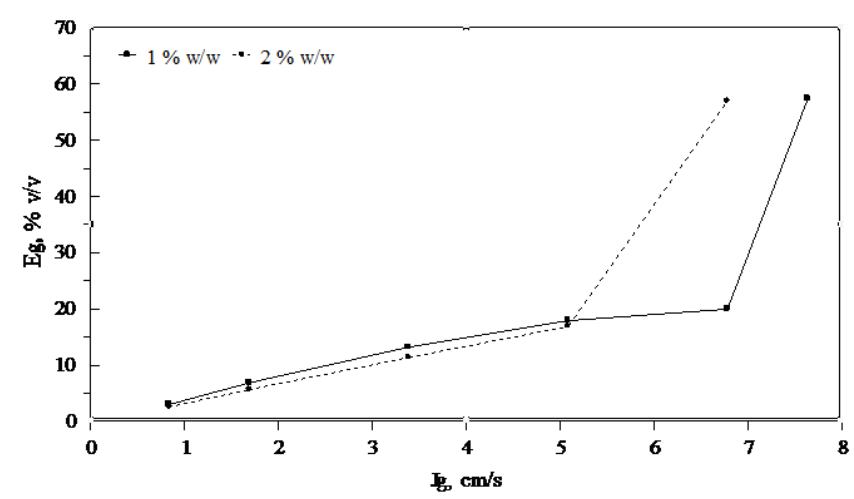

Figure 5. Gas hold-up in the downcomer for two solids content $(2 \%, \mathrm{w} / \mathrm{w})$ in the slurry. Surface tension of the liquid equal to $65 \mathrm{dyn} / \mathrm{cm}$. (90 ppm of frother MIBC).

Figure 5 shows that, under the same slurry velocities, there is not an appreciable difference in the behaviour of the gas hold-up in the down-comer when the slurry consistency is changed from 1 to $2 \%$ solids; however, the gas hold-up values are lower as compared with the gas hold-up in the equivalent gas-carbon slurry system without surfactant additions (see Figure 3), which indicates a decrease in bubble size as a result of the surfactant presence.

Even with the surfactant additions, the range of stability of the collection zone in terms of the superficial gas velocity maintained up to $5 \mathrm{~cm} / \mathrm{s}$. When the superficial gas velocity exceeds $5 \mathrm{~cm} / \mathrm{s}$, the increase in the slurry hydrophobic solids content appears to promote bubbles coalescence, since the gas hold-up in the down-comer increases markedly.

Figure 6 shows the gas hold-up behaviour in the downcomer under superficial silica slurry velocities from 5 to 21 $\mathrm{cm} / \mathrm{s}$; this figure compares the flotation system, under surfactant additions, containing $1 \%$ solids with that of $2 \%$ solids. 


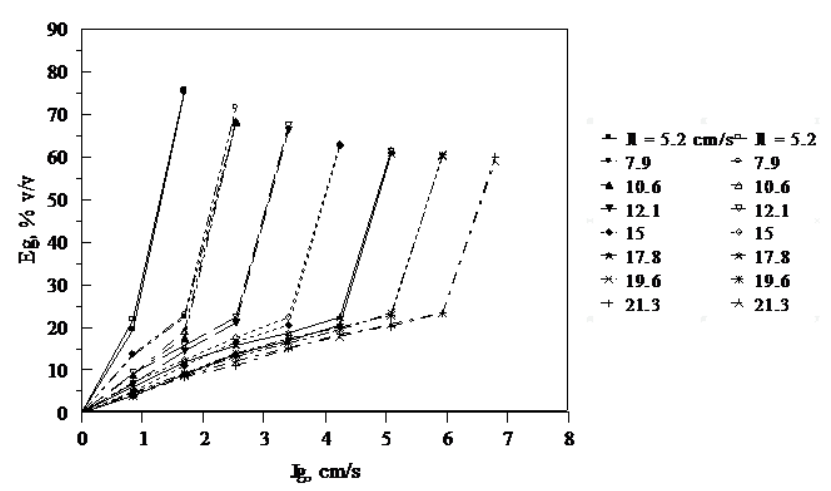

Figure 6. Changes on gas hold-up in the downcomer with the superficial gas and slurry velocities. The slurry is constituted by silica particles ( 1 and $2 \%$, w/w), and 20 ppm of surfactant.

The experimental measurements indicate that under surfactant additions the stability of the collection zone is maintained up to a gas hold-up value of $20 \%$ in the range of superficial slurry velocity between $5 \mathrm{~cm} / \mathrm{s}$ and $21 \mathrm{~cm} / \mathrm{s}$.

It can be seen that for each fixed value of superficial slurry velocity exist a particular maximum superficial gas velocity at which the collection zone is found; and, over that maximum value the collection zone is replaced by the jet zone. Under the last circumstances the flotation process becomes erratic and the operation is unstable.

These results show that in the downcomer stable operating zone, there is a linear relationship among the gas hold-up and the superficial gas velocity for every fixed condition of superficial slurry velocity, this may indicate that bubbles are more homogeneous in size and more evenly distributed in the down-comer, preventing bubbles coalescence because of the hydrophilic nature of the silica particles (and because the surfactant additions).

By using the experimental device depicted in figure 1, the gas hold-up and the superficial gas velocity were estimated in the separation cell, in order to observe the effect of the downcomer behaviour in the distribution of the gas dispersion in this separation cell. Figures 7 and 8 show the gas hold-up distribution in the separation cell as a function of the superficial gas velocity in the downcomer for a gascarbon slurry flotation system, and the gas-silica slurry system, respectively.

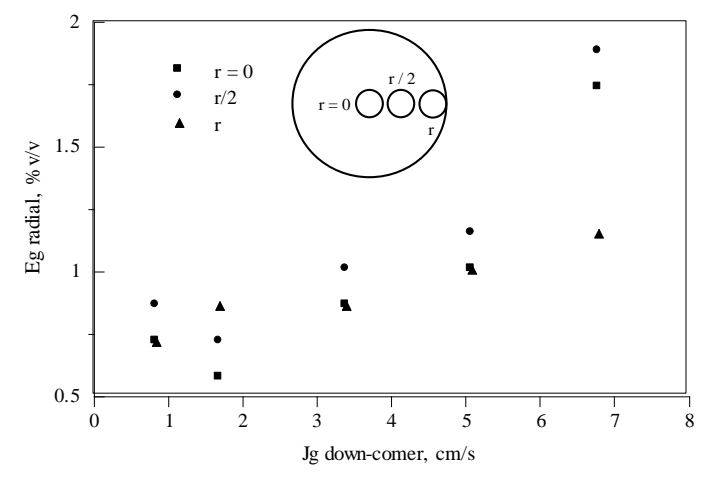

Figure 7. Radial distribution of the gas hold-up in the separation cell. Slurry made with carbon particles $(2 \%$, $\mathrm{w} / \mathrm{w})$, and surface tension of the liquid $=65 \mathrm{dyn} / \mathrm{cm}$.
Figure 7 shows a radial distribution of the gas content in the separation cell for a carbon-water slurry. It is noticed that the radial gas hold-up differences in the separation cell are maintained when the superficial gas velocity in the downcomer does not exceed $5 \mathrm{~cm} / \mathrm{s}$, being lower in the center of the cell $(r=0)$, indicating that the larger gas bubbles float in that region; however, when the superficial gas velocity in the downcomer exceeds the $5 \mathrm{~cm} / \mathrm{s}$, the gas hold-up becomes lower close to the wall of the separation cell as a result of a high circulation and mixing produced by the operating conditions.

Radial differences in superficial gas velocity and gas holdup will promote circulation and mixing in the separation cell, which will induce turbulences affecting the metallurgical performance of the process.

Figure 8 presents the experimental gas hold-up values in the radial direction in the separation cell when the flotation system consisted of gas-silica slurry. It can be observed that there are small radial differences in gas hold-up all the way through the operating conditions of the downcomer.

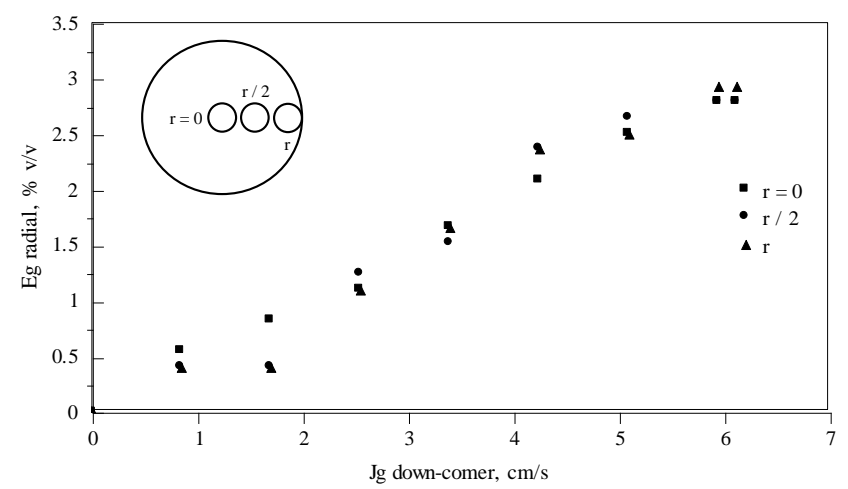

Figure 8. Radial distribution of the gas holdup in the separation cell. Slurry made with silica particles (2\%, $\mathrm{w} / \mathrm{w})$, surface tension $=71 \mathrm{dyn} / \mathrm{cm}(20 \mathrm{ppm}$ of MIBC$)$.

The radial gas distribution pattern in the silica slurry $(2 \%$, $\mathrm{w} / \mathrm{w}$ solids) is maintained through the entire range of superficial gas velocity in the downcomer. The gas hold-up tends to decrease slightly as the measurement point is farther from the downcomer; this indicates that the gas bubbles are homogeneous in diameter, and the downcomer operation is mainly affected by the type of solids in the slurry.

These observations suggest that gas bubbles are exceptionally uniform in size and distribution in the radial direction of the separation cell, which may be explained by the hydrophilic nature of silica that prevents bubbles to collide and eventually to coalesce.

\section{CONCLUSIONS}

The experimental results from this work show that the operation of the downcomer in the Jameson cell is affected by the superficial gas velocity, the superficial slurry velocity, and the hydrophobic - hydrophilic nature of the solids in the slurry. 
The presence of a collection zone in the downcomer depends on the balance between the superficial gas velocity and the superficial slurry velocity. Unbalanced gas-slurry operations of the downcomer produce the unsteadiness of the collection zone in such a way that the entire downcomer is occupied by a free slurry jet. Under these circumstances the separation process of hydrophobic particles by the gas bubbles in the downcomer does not exist, and the behaviour of the device as an inverted flotation column does not succeed.

It was observed that the presence of hydrophobic solids in the slurry induces bubbles coalescence in the downcomer, producing a given distribution of bubbles that is reflected in a remarkable turbulent behaviour in the separation cell. On the contrary, slurries consisted of hydrophilic solids prevent the bubbles coalescence, and produce more homogeneous size of bubbles as well as a stable packed bubbles fluidized bed in the down-comer.

Invariably, the process produces differences of gas content in the radial direction of the separation cell. However, these differences are larger when slurries consisted of hydrophobic solids. Therefore, the circulation, and mixing, in the separation cell is enhanced by the production of large bubbles in the downcomer, particularly, under high gas and slurry flow rates.

\section{REFERENCES}

[1] Dawson, W. J., Yannoulis, G. F., Atkinson, B. W., Jameson, G. J. 1996. Applications of the Jameson cell in the Australian coal industry. In Column'96. Proceedings of the International Symposium on Column Flotation, The Met. Soc. Of CIM, pp. 233-246.

[2] Clayton, R. L. 1994. Recovering organic from raffinate using Jameson cells. A paper presented at Arizon AIME Conference, Tucson, AZ, December 1994, pp. 1-12.

[3] Dawson, W. J., Jackson, B. R. 1995. Evolution of Jameson cells for solvent extraction applications. A paper presented at Copper Hydrometallurgy Forum, Brisbane, Australia, September, 1995, pp. 1-10.

[4] Maxwell, J. C. 1892. A Treatise of Electricity and Magnetism. Vol. 1 Oxford Univ. Press, Part II, pp. 435449.

[5] Koh, P.T.L., and Schwarz, M.P. 2009. CFD Models of microcell and Jameson flotation cells. Proceedings of the Seventh International Conference on CFD Minerals and Process Industries CSIRO, Melbourne, Australia, pp 1-6.

[6] Tasdemir, T., Tasdemir, A., and Oteyaka, B. 2011. Gas entrainment rate and flow characterization in downcomer of a Jameson cell. Physicochemical Problems of Mineral Processing. Vol 47, pp 61-78.

[7] Tasdemir, T., Tasdemir, A., and Gecgel, Y. 2011. Removal of fine particles from waste water using induced air flotation. The Online Journal of Science and Technology. Vol. 1, No. 3, pp 14-22.

[8] Tavera, F. J., Gomez, C. O., Finch, J. A. 1996. Novel gas holdup probe and application in flotation columns. Trans. Inst. Min. Metall. 105, pp. C99-C104.
[9] Tavera, F. J., Escudero, R., Gomez, C. O., Finch, J. A. 1997. Gas holdup and slurry conductivity as process diagnostics in column flotation. In Proceedings of the International Symposium on Processing of Complex Ores, The Met. Soc. Of CIM, pp. 3-20.

[10] Tavera, F. J., Gomez, C. O., Finch, J. A. 1998. Conductivity flow cells for measurements on dispersions. Can. Metall. Quart. 37 (1), 19-25.

[11] Tavera, F. J., Escudero, R. 2010. On-line superficial bubble surface flux measurements in mineral flotation systems. Proceedings of the Symposium on Chem. Engng. And Environmental Tech., Aguascalientes, México, pp 170-176.

[12] Tavera, F. J. 1996. Ph. D. Thesis, McGill University, Montreal, Canada.

[13] Spyridopoulos, M., Simons, S., Neethilng, S., Cillers, S. 2004. Effect of humic substances and particles on bubble coalescence and foam stability in relation to dissolved air flotation process. Physicochemical Problems of Mineral Processing, 38, pp. 37-52.

[14]Tse, K. L., Martin, T., McFarlane, C. M., Nienow, A. W. 2003. Small bubble formation via a coalescence dependent break-up mechanism. Chemical Engineering Science, 58 (2003), pp. 275-286. 